\title{
CHARACTERISTICS AND EFFECTIVENESS OF CHITOSAN ORININATED FROM THE CARAPACE OF T. ANOMALA SHRIMP AS AN ANTIBACTERIAL COMPOUND
}

\section{KARAKTERISTIK DAN EFEKTIVITAS KITOSAN KARAPAS UDANG RAMA-RAMA (Thalassina anomala) SEBAGAI SENYAWA ANTIBAKTERI}

\author{
Tengku Muhammad Ghazali ${ }^{1}$, Rahman Karnila ${ }^{1}$, Dewita ${ }^{1}$ \\ ${ }^{1}$ Kekhususan Teknologi Hasil Perikanan Magister Ilmu Kelautan, Pascasarjana Universitas Riau, Pekanbaru, Jl. HR Soe \\ brantas Km 12,5 Simpang Baru, Panam - Pekanbaru, Indonesia 28293 - Correspondence Author : \\ Ghazali.tengku@gmail.com
}

\begin{tabular}{|c|c|}
\hline I N F O & A B S T R A C T \\
\hline $\begin{array}{l}\text { Diterima: } 25 \text { Desember } 2018 \\
\text { Disetujui: 26 Januari } 2019\end{array}$ & $\begin{array}{l}\text { This study aims to investigate the inhibition zones of the chitosan against } \\
\text { Pseudomonas aeruginosa. Carapace from } T \text {. anomala is used as raw material of }\end{array}$ \\
\hline $\begin{array}{l}\text { Keywords: } \\
\text { Thalassina anomala } \\
\text { citosan, } \\
\text { resistor zone bacteria }\end{array}$ & $\begin{array}{l}\text { chitosan. There were } 5 \text { treatments used, namely positive control }\left(\mathrm{K}_{0+}\right) \text {, negative } \\
\text { control }\left(\mathrm{K}_{0-}\right), 5 \% \text { chitosan }\left(\mathrm{K}_{1}\right), 7 \% \text { chitosan }\left(\mathrm{K}_{2}\right) \text { and } 9 \%\left(\mathrm{~K}_{3}\right) \text { chitosan. The } \\
\text { carapace was taken and then washed, dried, refined, demineralization, de- } \\
\text { preoteinated, deasitelation and was tested using double layer method, discs and well } \\
\text { diffusion. The proximate carapace test results were as follows, water content was } \\
68.18 \% \text { gross wight }(\mathrm{gw}) \text {, moisture content } 11.77 \% \text { dry wight (dw) protein } \\
\text { content, } 2.35 \% \mathrm{dw} \text { fat content, } 84.43 \% \mathrm{dw} \text { ash content and carbohydrate content } \\
\text { was } 1.45 \% \mathrm{dw} \text {. The chitosan of } T \text {. anomala characteristics were yellowish white } \\
\text { flakes, odorless and tasteless with yield value, moisture content, ash content, } \\
\text { mineral content }(\mathrm{Ca}, \mathrm{Fe}, \mathrm{K}, \mathrm{Na}, \mathrm{P}) \text { and the degree of deacetylation } 27.51 \% ; 7.31 \\
\% \mathrm{gw} ; 3.40 \% \mathrm{dw} ; 12.17 \mathrm{mg} / \mathrm{L} ; 4.90 \mathrm{mg} / \mathrm{L} ; 3.40 \mathrm{mg} / \mathrm{L} ; 5.49 \mathrm{mg} / \mathrm{L} ; 0.27 \mathrm{mg} / \mathrm{L} ; \text { and } \\
73.43 \% \text { respectively, Results on antimicrobial sensivity tests using double layer, } \\
\text { disk blank and well diffusion. Shown clear zone, } 13.87 \mathrm{~mm}, 11.34 \mathrm{~mm} \text { and } 14.62 \\
\text { mm. these values indicate that the antimicrobial effect of the chitosan is strong. }\end{array}$ \\
\hline
\end{tabular}

\section{PENDAHULUAN}

Udang rama-rama (Thalassina anomala) merupakan komoditi perikananan di Kepulauan Meranti Provinsi Riau, memiliki cita rasa gurih. Saat ini udang rama-rama salah satu komoditi perikanan yang masih belum terdata secara stastik di dinas perikanan setempat, namun memiliki potensi hasil perikanan dikarenakan melimpahnya udang tersebut disepanjang pesisir perairan mangrove daerah Selat Panjang yang sebagian dimanfaatkan hanya sebagai lauk pauk dan belum ada suatu usaha untuk memanfaatkannya lebih lanjut karena nilai ekonomisnya cukup rendah sekitar Rp. 4.000-7.000/ kilogram, namun daya tahan hidupnya sangat tinggi bila terpisahkan dari habitat aslinya.

Morfometrik tubuh udang rama-rama memiliki bagian yang dapat dimanfaatkan seperti daging yang berkisar $17 \%$ dari seluruh tubuh dan bagian karapas bekisar $70 \%$ tidak dimanfaatkan. Salah satu alternatif pemanfaatan limbah karapas udang rama-rama untuk meningkatkan nilai ekonomis dan daya guna dengan memanfaatkan limbah udang rama-rama menjadi berbagai produk seperti kitin dan kitosan.

Kitosan merupakan polimer kationik yang bersifat nontoksis, dapat mengalami biodegradasi dan biokompatiel, kitosan juga memiliki kegunaan yang sangat luas dalam kehidupan sehari-hari seperti 
absorben limbah logam berat, zat warna, pengawet, antijamur, antibakteri, kosmetik, farmasi, flokulan, dan antikanker, kitosan dapat aktif dan berinteraksi dengan sel, enzim atau matrik polimer yang bermuatan negatif (Purnawan, 2008).

Berdasarkan penelitian yang dilakukan oleh Farouk et al, (2007), H. scabra berpotensi sebagai antibakteri terhadap bakteri pembusuk yaitu Pseudomonas aeruginosa. Menurut Purwani et al, (2008), bakteri tersebut merupakan bakteri pembusukan pada ikan. Bakteri tersebut berpotensi menyebabkan pembusukan karena aktivitasnya dalam mendegradasi protein pada ikan. Protein digunakan bakteri untuk aktivitas metabolismenya. Pendapat tersebut diperkuat oleh Jay (2005), bakteri pembusuk yang terdapat pada ikan diantaranya adalah Pseudomonas (32-60\%) namun saat ini bakteri tersebut resisten terhadap antibiotic.

P.aeruginosa merupakan salah satu bakteri yang resisten terhadap beberapa bahan antimikrobial yang ada. Resistensi tersebut disebabkan penggunaan bahan antimikrobial yang tidak tepat (Mayasari, 2006). Maka perlunya penelitian daya hambat dengan antibiotik alami terhadap Multi-Drug Resistant (MDR) P. aeruginosa.

Penelitian tentang kitosan sebagai antibakteri terhadap bakteri MDR P.aeruginosa saat ini, masih jarang informasi mengenai berapa daya hambat kitosan terhadap MDR P.aeruginosa dengan konsentrasi berbeda. Oleh karena itu, dalam penelitian ini untuk mengetahui karakteristik dan efektivitas kitosan dari karapas udang rama-rama sebagai senyawa antibakteri.

\section{METODE PENELITIAN}

\section{Bahan dan Alat}

Bahan utama yang digunakan dalam penelitian ini terdiri dari sampel Udang rama-rama ( $T$. anomala) dengan ukuran $28 \mathrm{~cm}$ yang diperoleh dari Selat Panjang, Riau. Bahan kimia lainya merupakan bahan untuk penyiapan serta analisis sampel yaitu $\mathrm{H}_{2} \mathrm{SO}_{4} 37 \% \mathrm{HCl} 0,1 \mathrm{~N}, \mathrm{NaOH} 3 \mathrm{~N}$, $\mathrm{NaOH} 30 \%$, NaOH 20\%, Hexana, Alkohol 70\%, , Indikator PP, asam sulfat $\left(\mathrm{H}_{2} \mathrm{SO}_{4}\right)$ pekat, katalis Kjeldhal Tab, $\mathrm{NaOH} 45 \%$, asam borat $\left(\mathrm{H}_{3} \mathrm{BO}_{3}\right) 20 \%$, indikator campuran, kloroform, $\mathrm{HNO}_{3}, \mathrm{HClO}_{4}$, Kalium Karbonat, larutan stok $\mathrm{Ca}$, dan lanta $\left(\mathrm{LaCl}_{3} \cdot 7 \mathrm{H}_{2} 0\right)$, sedangkan untuk bahan analisis mikrobiologi yaitu Nutrient Agar (NA), Kultur MDR P.aeruginosa diperoleh dari Rumah Sakit Kariyadi, Semarang. Bahan habis pakai adalah Kertas cakram, almunium foil, Tissue, kertas label, sarung tangan, masker, aquades 100 Liter.

Alat yang digunakan pada penelitian ini adalah nampan, blender, magnetic stirrer, timbangan analitik, kertas saring ukuran 60 mesh, Erlenmeyer $100 \mathrm{ml}$, Erlenmeyer $1000 \mathrm{ml}$, gelas piala, pipet volumetrik, bulp, cawan porselen, gelas ukur, timbangan digital $(0,00 \mathrm{~g}$ dan $0,000 \mathrm{~g})$ tabung reaksi, Hot plate, pengaduk kaca, oven, labu Kjeldhal, tabung Soxhlet, stainless pelubang $7 \mathrm{~mm}$, spektrofotometer nic 20D, dan Atomic Absorption Spectrophotometer (AAS), cawan petri, jarum ose, Autoclave HVE-50, jarum ose, kertas cakram 6 mm, Mikro pipet, Pembakar bunsen, vortex,Tabung reaksi, incubator, kertas saring whatman no.42, Laminar Flow Cabinet, kertas cakram whatman no.2, jangka sorong $(0,05 \mathrm{~mm})$ dan rak tabung.

\section{Prosedur Penelitian}

Penelitian ini dilakukan dalam tiga tahapan, yaitu: 1) penyiapan dan analisis kimia sampel udang rama-rama (T. anomala), 2) ekstraksi dan analisis kimia kitin dan kitosan, 3) ekstraksi kitosan dan uji daya hambat bakteri:

\section{Penyiapan Sampel}

Udang rama-rama yang diperoleh dengan keadaan masih hidup dicuci dan ditimbang. Udang tersebut dipisahkan bagian cangkang, daging, isi perut, dan lain-lain. Karapas dicuci dengan menggunakan air dan disikat untuk menghilangkan sisa-sisa daging yang melekat pada karapas. kemudian karapas dikeringkan di dalam oven selama 48 jam selanjutnya, dihaluskan dengan blender dan di analisis kadar air, abu, protein, lemak dan analisis mineral (Ca, K, Na, Fe dan P). 


\section{Ekstraksi Kitin dan Kitosan}

Ekstraksi kitin dan kitosan mengacu pada prosedur Suptijah (2004). Proses preparasi kitin mencakup proses demineralisasi, deproteinasi dan pengeringan, dan kitosan diperoleh dari deasetilasi kitin. Karapas udang rama-rama yang telah dihaluskan didemineralisasi dengan larutan $\mathrm{HCl} 1 \mathrm{~N}$ (rasio cangkang dan larutan $\mathrm{HCl}$ 1:7 (b/v)) selama 1 jam pada suhu $\pm 90^{\circ} \mathrm{C}$. Hasil proses demineralisasi selanjutkan diendapkan untuk memisahkan padatan dan cairan dengan cara di diamkan. Padatan yang diperoleh di cuci 3 kali dengan aquades untuk menetralkan $\mathrm{pH}$ mendekati $\mathrm{pH}$ 7. Padatan kemudian dideproteinasi dengan larutan $\mathrm{NaOH} 3 \mathrm{~N}$ (rasio padatan dan larutan $\mathrm{NaOH}$ 1:10 (b/v)) selama 1 jam pada suhu $\pm 90{ }^{\circ} \mathrm{C}$. Hasil proses deproteinasi selanjutkan diendapkan untuk memisahkan padatan dan cairan dengan cara didiamkan bagian padatan terpisah dari cairannya. Padatan yang diperoleh dicuci berulang kali dengan air keran untuk menetralkan $\mathrm{pH}$ hingga mendekati $\mathrm{pH}$ 7. Padatan dikeringkan dalam oven pada suhu $60^{\circ} \mathrm{C}$ selama 6 jam. Kitin yang terbentuk di analisis terhadap kadar air, abu, nitrogen dan derajat deasetilasi.

Kitosan diperoleh dengan mengdeasetilasi kitin menggunakan larutan $\mathrm{NaOH} 30 \%$ (rasio kitin dan larutan $\mathrm{NaOH} \mathrm{1:2(b/v))} \mathrm{selama} 1$ jam pada suhu $\pm 100^{\circ} \mathrm{C}$. Hasil proses deasetilasi selanjutkan diendapkan untuk memisahkan padatan dan cairan dengan cara didiamkan bagian padatan terpisah dari cairannya. Padatan yang diperoleh dicuci berulang kali dengan air keran untuk menetralkan $\mathrm{pH}$ hingga mendekati $\mathrm{pH}$ 7. Padatan dikeringkan dalam oven pada suhu $60{ }^{\circ} \mathrm{C}$ selama 6 jam. Kitosan yang terbentuk dianalisis terhadap kadar air, abu, nitrogen dan derajat deasetilasi.

\section{Sterilisasi Alat}

Sterilisasi merupakan usaha yang dilakukan untuk membebaskan alat dan bahan dari mikroorganisme kontaminan. Sterilisasi dapat dilakukan dengan cara mencuci alat-alat yang akan digunakan sampai bersih, setelah kering alat-alat dibungkus menggunakan kertas padi, hal ini bertujuan untuk mencegah alat-alat tersebut terkena air, selanjutnya alat-alat tersebut dimasukkan ke dalam autoclave untuk disterilisasi dengan suhu $121^{\circ} \mathrm{C}$, tekanan $2 \mathrm{~atm}$ selama 15 menit.

\section{Pembuatan Media NA (Nutrient Agar)}

Pembuatan media NA dicampurkan akuades sesuai dengan perbandingan yang telah ditentukan, yaitu $22 \mathrm{~g} / \mathrm{L}$ akuades, selanjutnya larutan dihomogenkan menggunakan magnetic stirrer di atas hot plate hingga larutan mendidih. Setelah mendidih, larutan disterilkan menggunakan autoclave dengan suhu $121^{\circ} \mathrm{C}$, tekanan 2 atm selama 15 menit, dan kemudian dipindahkan ke laminar flow. Setelah mencapai suhu $45-50^{\circ} \mathrm{C}$, secara aseptic media dituangkan kedalam cawan petri dan atau tabung reaksi yang ditutup menggunakan kapas dan aluminium foil. Apabila media tidak langsung digunakan, dapat disimpan dalam refrigerator.

\section{Pembuatan Media NB (Nutrient Broth)}

Pembuatan media NB dicampurkan akuades sesuai dengan perbandingan yang telah ditentukan, yaitu $6 \mathrm{~g} / \mathrm{L}$ akuades, kemudian larutan dihomogenkan menggunakan magnetic stirrer diatas hot plate hingga Larutan mendidih. Setelah mendidih, larutan disterilkan menggunakan autoclave dengan suhu $121^{\circ} \mathrm{C}$, tekanan 2 atm selama 15 menit, dan kemudian dipindahkan ke laminar flow, setelah mencapai suhu $45-50^{\circ} \mathrm{C}$, secara aseptic media dituangkan kedalam tabung reaksi yang ditutup menggunakan kapas dan aluminium foil.

\section{Peremajaan Isolat Pseudomonas aeruginosa}

Isolat stok bakteri P.aeruginosa yang digunakan dalam penelitian ini berasal dari rumah sakit karnadi semarang. Biakan murni bakteri diremajakan pada media NA dengan cara menggoreskan jarum ose yang mengandung bakteri P.aeruginosa secara aseptic, yaitu mendekatkan cawan petri pada nyala api saat menggoreskan jarum ose, kemudian diinkubasi di dalam incubator selama 24 jam pada suhu $37^{\circ} \mathrm{C}$.

\section{Pembuatan Suspensi Bakteri Pseudomonas aeruginosa}

Pembuatan suspensi bakteri dengan cara mengambil biakan menggunakan jarum ose, dimasukkan kedalam media NB dan diinkubasi didalam incubator selama 24 jam pada suhu $37^{\circ} \mathrm{C}$. Suspensi bakteri yang akan digunakan terlebih dahulu disetarakan dengan larutan standar Mc Farland 1 yang kepadatan bakterinya setara dengan $10^{8} \mathrm{CFU} / \mathrm{mL}$. Penyetaraan suspensi bakteri dilakukan 
dengan cara pengenceran serial, tabung pertama berisi $10 \mathrm{~mL} \mathrm{NB}$ dan tabung kedua, ketiga dan seterusnya berisi $9 \mathrm{~mL}$ NB. Sebelum diambil $1 \mathrm{~mL}$, terlebih dahulu tabung divortex dahulu agar homogeny. Setelah semua tabung selesai dilakukan pengenceran, kemudian tabung disetarakan dengan larutan Mc Farland (Sudarno et al, 2011).

$>$ Larutan kitosan dibuat dengan melarutkan kitosan sesuai dengan konsentrasi ke dalam larutan asam asetat $1 \%$ (Garriga et al, 2002).

> Pembuatan larutan kontrol positif dilakukan dengan cara menimbang serbuk K0+ sebanyak 250 mg kemudian ditambahkan dengan etanol 96\% sebanyak $500 \mu$ l (Hutabarat, 2016). Sedangkan pembuatan kontrol negatif yaitu $1 \mathrm{ml}$ Asam asetat di tambahkan $99 \mathrm{ml}$ aquades lalu aduk hingga homogen.

$>$ Metode difusi sumuran

- Media yang telah diinokulasi kultur bakteri uji tersebut dituang ke dalam cawan hingga homogen dan dibiarkan hingga membeku.

- Kemudian dibuat lubang (sumur) secara aseptis dengan diameter $7 \mathrm{~mm}$ dengan alat pelubang

- pemasukan larutan kitosan sebanyak $60 \mu \mathrm{L}$ yang mengandung kitosan dengan konsentrasi 5; 7 ; dan $9 ;(\mathrm{b} / \mathrm{v})$.

- Inkubasi pada waktu tertentu sesuai dengan kondisi optimum mikroba (24 jam) dan hitung zona hambatnya.

Metode cakram (Disc) (Pelczar et al, 1998).

- Pencampuran media Nutrient Agar dan kultur bakteri P.aeruginosa lalu pada suhu $37{ }^{\circ} \mathrm{C}$ hingga homogen, lalu dinginkan.

- Kertas cakram diletakkan di atas media dan di beri larutan ekstrak kitosan 5,7 dan 9\% sebanyak $1 \mathrm{ml}$.

- Inkubasi pada waktu tertentu sesuai dengan kondisi optimum mikroba (24 jam).

- Daerah bening dapat dilihat disekeliling kertas cakram yang menunjukan zona hambat pertumbuhan mikroba.

\section{Rancangan Dan Analisis Data}

Jenis penelitian yang digunakan pada penelitian ini adalah ekperimen dengan analisis data secara deskriptif. Khusus untuk tahap penelitian 3 (Konsentrasi kitosan), kontrol positif (Kloramohenikol) dan kontrol negatif (asetat). Rancangan percobaan penelitian ini adalah rancangan acak lengkap dengan menggunakan 3 ulangan untuk setiap perlakuan. Faktor dari penelitian ini adalah konsentrasi kitosan, kontrol positif dan negatif dengan tiga variasi konsentrasi, sehingga total unit percobaan yaitu 15 unit. Model rancangan yang digunakan adalah:

Keterangan :

$$
\mathrm{Yij}=\mu+\alpha \mathrm{i}+\varepsilon \mathrm{ij}
$$

Yij $\quad=$ Nilai pengamatan dari perlakuan ke-i pada ulangan ke-j

$\mu \quad=$ Nilai rataan umum

$\alpha \mathrm{i} \quad=$ Pengaruh perlakuan ke-i terhadap respon

cij = Pengaruh acak yang timbul pada perlakuan ke-i dan ulangan ke-j

Hipotesis yang akan diuji adalah sebagai berikut:

H0: $\alpha \mathrm{i}=\alpha$ (perbedaan konsentrasi Kitosan tidak memberikan hasil yang berbeda terhadap bakteri)

H1: $\alpha \mathrm{i} \neq \alpha$ (perbedaan konsentrasi memberikan hasil yang berbeda terhadap bakteri).

Hasil sidik ragam yang menunjukkan pengaruh nyata dilakukan uji Duncan pada selang kepercayaan $99 \%$. Rancangan perlakuan dan taraf perlakuan kitosan konsentrasi berbeda untuk antibakteri terhadap bakteri yang resisten disajikan pada Tabel 1.

\section{HASIL DAN PEMBAHASAN}


Udang yang digunakan dalam penelitian ini adalah udang rama-rama (T. anomala) dengan umur berkisar antara 7-9 bulan, berdasarkan kejadian empiris melalui hasil wawancara nelayan. Morfologi umum udang rama-rama berbentuk beruas-ruas, panjang karapas sekitar $40 \%$ dari panjang total. Bentuk tubuh secara umum seperti kalajengking, dengan bentuk karapas yang kokoh, capit besar dan tubuh berwarna merah orange, terdapat setae (rambut halus) pada ujung kaki jalan dan pada lateral abdomen. Bagian abdomennya berwarna putih dan pada udang betina terkadang terdapat telur pada kaki renang di bagian ventral abdomen.

\section{Preparasi Bagian Tubuh Udang Rama-Rama}

Tubuh udang rama-rama secara garis besar terbagi atas empat bagian utama yaitu karapas, daging, isi perut (kotoran dan air) dan gonad, sedangkan proporsi setiap bagian tubuh tersebut dapat di lihat pada Tabel 2. Secara umum tubuh udang rama-rama terdiri dari karapas, daging,isi perut dan gonad dengan rasio adalah $19: 6: 9: 1(\mathrm{~b} / \mathrm{b})$.

\section{Analisis Kimia (Proksimat) Daging Dan Karapas Udang Rama-Rama}

Hasil analisis proksimat yang dilakukan pada penelitian ini bertujuan untuk mengetahui komposisi protein, lemak, air, dan abu daging dan karapas. Hasil analisis proksimat daging dan karapas dapat dilihat pada Tabel 3.

Kadar air daging udang rama-rama yaitu 79,17 \%bb memiliki kadar air relative tinggi. Kadar air sangat berpengaruh terhadap konsistensi bahan pangan, dimana sebagian besar bahan pangan segar mempunyai kadar air 70 persen atau lebih. Yanar et al, (2011) mengemukakan kandungan nutrisi udang liar bekisar 75,18 \%, sedangkan pada karapas 63,18 \% kadar airnya diduga masih melekatnya jaringan tubuh, sisa kotoran dan air yang berada dalam karapas. tingginya kadar protein $92,38 \%$ bk pada daging dapat dimanfaatkan menjadi konsentrat protein (Dewita, 2018), sedangkan pada karapas memiliki nilai $11,77 \%$ bk.

\section{Analisis kimia tepung karapas udang rama-rama}

Tepung yang dihasilkan berwarna abu kemerah-merahan dengan tekstur kristal dan butiran halus, beraroma kuat khas udang. Tepung karapas udang rama-rama dianalisis terhadap karakteristik kimia dan hasilnya disajikan pada Tabel 4. Tepung karapas udang rama-rama lebih rendah kadar airnya $2,62 \%$ dari tepung udang vanname yaitu 5,61\% (Istifa, 2010). Perbedaan nilai kadar ini diduga dipengaruhi oleh tingkat kekeringan sampel saat preparasi, salah satunya adalah saat proses pengeringan sampel.

\section{Karakteristik kimia kitin dan kitosan karapas udang rama-rama}

Menunjukan kitin memiliki karakteristik berupa warna merah kecoklatan muda memiliki bentuk kristal dan dan dapat terurai secara hayati (biodegradable) sedangkan kitosan berbentuk serpihan putih kekuningan, tidak berbau dan tidak berasa. Adanya beberapa variasi konfigurasi seperti butiran, membran, pelapis kapsul, serat dan spons, yang tidak larut dengan air dengan polianion dapat juga digunakan untuk pembuatan butiran gel, kapsul, dan membran (Purwantiningsih, 2009).

Perbedaan rendemen kitin dan kitosan yang dihasilkan disebabkan oleh proses pemutusan ikatan asetil (deasetilasi) pada kitosan. Pemutusan ikatan asetil pada proses hidrolisis kitosan menyebabkan penurunan ukuran molekul sehingga bobot molekul kitosan lebih ringan dibandingkan kitin. Rendemen kitin dan kitosan yang dihasilkan lebih tinggi dibandingkan kitin dan kitosan rajungan 45,08\% dan 20,64\% (Syukron, 2016).

Kadar abu kitosan udang rama-rama 3,41\% lebih tinggi daripada standar mutu yang telah ditetap yaitu $\leq 2 \%$, kitosan pada udang rama-rama belum memenuhi standar mutu kitosan yang telah ditetapkan (Protan Laboratories, 1992).

Tabel 1. Rancangan perlakuan dan taraf perlakuan kitosan Konsentrasi berbeda untuk antibakteri terhadap bakteri MDR P.aeruginosa

\begin{tabular}{lccc}
\hline \multirow{2}{*}{ Perlakuan } & \multicolumn{3}{c}{ Ulangan } \\
\cline { 2 - 4 } Kontrol positif (Kloramphenical) $\left(\mathrm{K}_{0+)}\right.$ & $\mathrm{K}_{\mathrm{o+1}}$ & $\mathrm{K}_{\mathrm{o+2}}$ & $\mathbf{3}$ \\
\hline & & $\mathrm{K}_{\mathrm{o}+3}$
\end{tabular}


Kontrol negative (Asetat) $\left(\mathrm{K}_{0-}\right.$

$\mathrm{K}_{\mathrm{o}-1}$

Kitosan 5\% (K1)

Kitosan 7\% (K2)

Kitosan $9 \%(\mathrm{~K} 3)$

$\mathrm{K}_{11}$

$\mathrm{K}_{\mathrm{o}-2}$

$\mathrm{K}_{\mathrm{o}-3}$

$\mathrm{K}_{21}$

$\mathrm{K}_{31}$

$\mathrm{K}_{12}$

$\mathrm{K}_{13}$

$\mathrm{K}_{23}$

$\mathrm{K}_{32}$

$\mathrm{K}_{33}$

Tabel 2. Proporsi bagian tubuh udang rama-rama (T. anomala)

\begin{tabular}{lcc}
\hline Bagian tubuh udang rama-rama & Berat $(\mathrm{g})$ & Persentase bobot $(\%)$ \\
\hline Karapas & $97,69 \pm 0,14$ & $55,09 \pm 0,17$ \\
Daging & $30,45 \pm 0,13$ & $17,17 \pm 0,35$ \\
Isi perut & $44,07 \pm 0,11$ & $24,85 \pm 0,25$ \\
Gonad & $5,12 \pm 0,38$ & $2,89 \pm 0,44$ \\
\hline Total & $177,33 \pm 0,23$ & 100 \\
\hline
\end{tabular}

Tabel 3. Nilai proksimat daging dan karapas udang rama-rama

\begin{tabular}{lcc}
\hline Parameter & Daging (\%) & Karapas (\%) \\
\hline Air (bb) & $79,17 \pm 0,20$ & $63,18 \pm 0,21$ \\
Protein (bk) & $92,38 \pm 0,26$ & $11,77 \pm 0,13$ \\
Lemak (bk) & $1,03 \pm 0,32$ & $2,35 \pm 0,51$ \\
Abu (bk) & $0,63 \pm 0,81$ & $84,43 \pm 0,35$ \\
Karbohidrat (by difference) (bk) & $5,96 \pm 0,11$ & $1,45 \pm 0,73$ \\
\hline
\end{tabular}

Tabel 4. Kandungan kimia dan rendemen tepung karapas udang rama-rama

\begin{tabular}{lr}
\hline Kandungan & \multicolumn{1}{c}{ Karapas } \\
\hline Air $(\% \mathrm{bb})$ & $2,62 \pm 0,67$ \\
Abu (\%bk) & $64,65 \pm 0,26$ \\
Kalsium & $12,21 \pm 0,12$ \\
Besi & $5,30 \pm 0,22$ \\
Kalium & $2,36 \pm 0,14$ \\
Natrium & $22,71 \pm 0,57$ \\
Fosfor & $0,23 \pm 0,25$ \\
Rendemen $(\%)$ & $35,58 \pm 0,39$ \\
\hline
\end{tabular}

Tabel 5. Karakteristik kitin dan kitosan udang rama-rama

\begin{tabular}{lcc}
\hline Kandungan & Kitin & Kitosan \\
\hline Rendemen & $48,90 \pm 0,32$ & $27,51 \pm 0,34$
\end{tabular}



Air
$9,71 \pm 0,41$
$7,31 \pm 0,36$
Abu
$5,62 \pm 0,26$
$3,41 \pm 0,79$
Kalsium
$12,19 \pm 0,11$
$12,17 \pm 0,12$
Besi
$5,00 \pm 0,21$
$4,90 \pm 0,26$
Kalium
$3,37 \pm 0,24$
$3,40 \pm 0,13$
Natrium
$5,70 \pm 0,19$
$5,49 \pm 0,11$
Fosfor
$0,26 \pm 0,08$
$0,27 \pm 0,07$
Derajat destilasi
$43,30 \pm 0,33$
$73,43 \pm 0,23$

Tabel 6. Rata-rata diameter zona hambat pada bakteri MDR P. aeruginosa dengan metode cakram

\begin{tabular}{lc}
\hline Perlakuan & Cakram $(\mathrm{mm})$ \\
\hline $\mathrm{K}_{0+}$ & $12,36 \pm 1,15^{\mathrm{d}}$ \\
$\mathrm{K}_{0-}$ & $6,18 \pm 1,89^{\mathrm{a}}$ \\
$\mathrm{K}_{1}$ & $8,23 \pm 0,70^{\mathrm{b}}$ \\
$\mathrm{K}_{2}$ & $8,94 \pm 0,73^{\mathrm{b}}$ \\
$\mathrm{K}_{3}$ & $11,34 \pm 0,16^{\mathrm{c}}$ \\
\hline
\end{tabular}

Penurunan kadar kalsium pada kitin dan kitosan menunjukan adanya proses demineralisasi yang menggunakan larutan asam klorida, kalsium yang terhadap karapas crustasea dapat bereaksi seperti reaksi yang telah ditunjukkan diatas (Lesbani, 2011).

\section{Daya hambat ekstrak kitosan karapas udang rama-rama terhadap bakteri Pseudomonas} aeruginosa

Hasil uji lanjut Duncan menunjukkan diameter zona hambat pada metode cakram tertinggi terdapat pada perlakuan $K_{0+} 12,36 \mathrm{~mm}$ berbeda sangat nyata dengan $\mathrm{K}_{3} 11,34 \mathrm{~mm}, \mathrm{~K}_{2} 9,39 \mathrm{~mm}, \mathrm{~K}_{1}$ 
7,92 $\mathrm{mm}$ dan $\mathrm{K}_{0-} 6,35 \mathrm{~mm}$, sedangkan $\mathrm{K}_{3}$ berbeda sangat nyata dengan $\mathrm{K}_{2}, \mathrm{~K}_{1}, \mathrm{~K}_{0 \text { - }}$ dan $\mathrm{K}_{0+}$. Perlakuan $\mathrm{K}_{2}$ tidak berbeda nyata terhadap $\mathrm{K}_{1}$, namun berbeda nyata dengan $\mathrm{K}_{3}, \mathrm{~K}_{0+}$ dan $\mathrm{K}_{0 \text {-. }}$.

Kitosan memiliki kemampuan mekanisme sebagai antibakteri karena hal-hal berikut ini yaitu adanya interaksi antara molekul kitin atau kitosan yang bermuatan positif dan membran sel mikroba bermuatan negatif. Model ini interaksi tersebut dimediasi oleh gaya elektrostatik antara kelompok $\mathrm{NH}^{+3}$ terprotonasi dan residu negatif, diduga berkompetensi untuk berikatan dengan dengan $\mathrm{Ca}^{2+}$ pada permukaan membran. Interaksi elektrostatik ini menghasilkan pengaruh ganda yaitu; 1) dengan mendorong perubahan dalam sifat permeabilitas dinding membran bakteri, sehingga memprovokasi ketidakseimbangan osmotik internal dan akibatnya menghambat pertumbuhan bakteri; 2) adanya hidrolisis peptidoglikan di dinding mikroorganisme, yang menyebabkan kebocoran elektrolit intraseluler seperti ion kalium dan konstituen berkarbohidrat berbobot molekul rendah lainnya (misalnya protein, asam nukleat, glukosa, dan dehidrogenase laktat) sehingga menyebabkan bakteri kehilangan nutrisi untuk tumbuh. Mekanisme lainnya yaitu penghambatan sintesis mRNA dan protein melalui penetrasi kitosan ke dalam inti mikroorganisme, terhambatnya sintesis mRNA maka replikasi bakteri sulit terjadi ( Goy et al, 2009).

\section{KESIMPULAN}

Berdasarkan hasil penelitian ini mendapatkan kitosan dengan rendemen dengan nilai 27,51\%, sedangkan kitin, tepung karapas dan karapas udang rama-rama secara berurut adalah: 48,9 \%, 35,58\%, dan $55,09 \%$.

Kitosan dari karapas udang rama-rama memiliki karakteristik yaitu total rendemen kitin dan kitosan yang dihasilkan dari tepung cangkang udang rama-rama berturut-turut adalah $48,9 \%$ dan 41,5\%; kadar air 9,71\% dan 7,31\%, abu 5,62\% dan 3.12\%, kalsium 12,21 (mg/L) dan 12,17 (mg/L), besi 5,00 (mg/L) dan 4,90 (mg/L), kalium 3,37 (mg/L) dan 3,40 (mg/L), natrium 5,70 (mg/L) dan $5,49(\mathrm{mg} / \mathrm{L})$, fosfat $0,26(\mathrm{mg} / \mathrm{L})$ dan $0,27(\mathrm{mg} / \mathrm{L})$; dan derajat deasetilasi $43,30 \%$ dan 73,43 \%. Hasil pengujian di atas menunjukkan bahwa kitin dan kitosan yang dihasilkan memiliki karakteristik yang tidak jauh berbeda, kecuali rendemen, air, abu, derajat destilasi dan kadar airnya sesuai standart mutu.

Hasil uji sensifitas antimikroba dengan metode cakram dengan nilai $11,34 \mathrm{~mm}$ dimana kitosan dapat menghasilkan aktivitas antibakteri tergolong kuat.

\section{DAFTAR PUSTAKA}

Dewita, Syahrul, Desmelati. (2018). Functional characteristics of cookies containing snakehead (Ophiocephalus striatus) fish protein concentrate fortified with Chlorella sp. International J. of Oceans and Oceanography, 12, 43-52

Farouk, A.E., Faizal A.H.G., Ridzwan B.H.. (2007). New Bacterial Species Isolated from Malaysian Sea Cucumbers with Optimized Secreted Antibacterial Activity. American Journal of Biochemistry and Biotechnology, 64-69

Garriga M, Aymerich HM, Monfort JM. (1993). Bacteriocinogenic activity of Lactobacilli from fermentor sausages. Journal of Applied Bacteriology. 75, 142-148

Hutabarat, M A A, Sari, N I, Leksono T. (2016). Uji Efektivitas Antibakteri Ekstrak Rumput Laut (Eucheuma Cottonii) Terhadap Bakteri Bacillus Cereus dan Pseudomonas aeruginosa. Jurnal Perikanan,1-9

Jay, J. M. (2005). Modern Food Microbiology. Sevent Edition. p: 101-120. USA: Springer Science

Lesbani, A, Yususf, S, Melviani, R, A, M. Karakterisasi Kitin dan Kitosan dari Cangkang Kepiting Bakau (Scylla Serrata). Jurnal penelitian sains, 14, 3(C) 14307

Mayasari, Evita (2006). Pseudomonas aeruginosa; Karakteristik, Infeksi, dan Penanganan. 2006. Dari: http :// library.usu.ac.id

Nursyirwani., W. Asmara,A.E.T.H. Wahyuni dan Triyatno. (2011). Isolasi Bakteri Asam Laktat dari Usus Ikan Kerapu Macan (Epinephelus fuscoguttatus) dan Potensinya Sebagai antivibrio. Ilmu Kelautan, 16(2), 70-77 
Pelczar, M. J., E. C. S Chan. (1998). Dasar-dasar Mikrobiologi. Jakarta: UI-Press

Protan Lab. (1987). Cation Polymer for Recovery Valuable by Products from Processing Waste. Burgess

Purnawan, C., (2008). Kitosan dari Cangkang Udang dan Aplikasi Kitosan sebagai Bahan Antibakteri pada Kain Katun. Tersedia dari Thesis. Universitas Gadjah Mada, Yogyakarta

Purwani, E., Retnaningtyas, Dyah W. (2008). Pengembangan Pengawet Alami dari Ekstrak Lengkuas, Kunyit, dan Jahe pada Daging dan Ikan Segar. Tersedia dari Laporan penelitian Fakultas Ilmu Kedokteran Universitas Muhammadiyah, Surakarta

Purwatinigsih, S., Wukirsari, T., Sjahriza, A., Wahyono, D. (2009). Sumber Biomaterial Masa Depan. Bogor: IPB Press

Sudarno, F., A. Setiorini dan H. Suprapto. (2011). Efektivitas Ekstrak Daun Meniran (Phyllantus nururi) sebagai Antibakteri Edwarsiella tarda secara In Vitro. Fakultas perikanan dan Kelautan Universitas Airlangga, 3 (1), 103-108

Suherman B, (2018). Potensi Kitosan Kulit Udang Vannemei (Litopenaeus vannamei) Sebagai Antibakteri Terhadap Staphylococccus epidermidis, Pseudomonas aeruginosa, Propionibacterium agnes, dan Escherichia coli dengan Metode Difusi Cakram Kertas. Tersedia dari Universitas Indonesia Timur Makassar

Suptijah P. (2004). Tingkatan kualitas kitosan hasil modifikasi proses produksi. Jurnal Teknologi Hasil Perairan, 7 (1), 56-67

Syukron, F., R. Karnila dan B. Hasan (2016). Karakteristik Glukosamin Hidrokloroda (HCl GlcN) dari Kitin dan Kepiting Chitosan Biru Kolam (Portunus pelagicus). Tersedia dari Berkala Perikanan Terubuk. ISSN 0126-4265 